\title{
Subchronic Toxicity of Ethanol Extract of Bitter Melon PULP (Momordica Charantia L.) on Liver Function and Histopathological Changes in Wistar Rats
}

\author{
Welly Ratwita ${ }^{1, *}$, Maman Djamaludin', Hindun Sa'adah'2, Salsabilla Maharani ${ }^{3}$
}

Welly Ratwita ${ }^{1, *}$, Maman

Djamaludin', Hindun Sa'adah², Salsabilla Maharani ${ }^{3}$

'Departement of Pharmacology Faculty of Medicine Jenderal Achmad Yani University, INDONESIA.

${ }^{2}$ Departement of Anatomy Faculty of Medicine Jenderal Achmad Yani University, INDONESIA.

${ }^{3}$ Medical Study Program Faculty of Medicine Jenderal Achmad Yani University, INDONESIA.

\section{Correspondence}

\section{Welly Ratwita}

Departement of Pharmacology Faculty of Medicine Jenderal Achmad Yani University, INDONESIA

E-mail: wellyratwita@gmail.com

History

- Submission Date: 23-01-2021;

- Review completed: 24-04-2021

- Accepted Date: 03-05-2021.

DOI : 10.5530/pj.2021.13.122

Article Available online http://www.phcogj.com/v13/i4

Copyright

(C) 2021 Phcogj.Com. This is an openaccess article distributed under the terms of the Creative Commons Attribution 4.0 International license.

\begin{abstract}
Bitter melon (Momordica charantia L.) is a plant that used as herbal medicine. It contains bioactive components which have hypoglycemic activity, immunomodulators, cancer chemoprevention, antiviral, antimicrobial, and inhibits oxidative stress and inflammation. The purpose of this study was to assess the degree of liver damage by macroscopic and microscopic examination. The sample consisted of 40 rats divided into 4 groups, Group 1 , control group, was only given aquadest and pellets. Group 2-4 were treated with ethanol extract of bitter melon pulp $250 \mathrm{mg} / \mathrm{kgbw}, 500 \mathrm{mg} / \mathrm{kgbw}$, and $1000 \mathrm{mg} / \mathrm{kgbw}$ during 28 days. On the $29^{\text {th }}$ day, the termination was carried out, aspartate and alanin aminotransferase (AST/ALT) being measured, the liver being observed for the macroscopic and microscopic morphology. Kruskal-Wallis test showed there was no significant difference in relative organ weight ( $p=0.177$ ), liver macroscopy morphology $(p=0.207)$. Microscopic observation for liver fibrosis using Metavir scoring system showed highest mean liver fibrosis score in dose 1000 $\mathrm{mg} / \mathrm{kgbw}$. Kruskal-Wallis test for microscopic changes showed significantly difference in male rats $(p=0.001)$ and female rats $(p=0.002)$. Based on these study, we conclude that ethanol extract of bitter melon pulp at a dose of $250 \mathrm{mg} / \mathrm{kgbw}, 500 \mathrm{mg} / \mathrm{kgbw}$, and $1000 \mathrm{mg} / \mathrm{kgbw}$ affect liver function significantly. But there's no subchronic toxicity effect on relative organ weight and macroscopic changes in liver morphology. Otherwise there was subchronic toxicity effect on changes in the microscopic structure of the liver characterized by the formation of fibrosis in the liver portal triad of experimental animals.
\end{abstract}

Key words: Momordica charantia L., Subchronic toxicity, Liver function, Histopathological changes.

\section{INTRODUCTION}

Indonesia as tropical country has million plants that used as medicinal plants, both wild and cultivated plants. The cost of conventional medical treatment which is not cheap and the tendency to change lifestyle back to nature are the reasons why medicinal plants are sought after as alternative medicine. ${ }^{1}$ One of the most wanted medicinal plants is bitter melon or bitter melon. ${ }^{2}$

Bitter melon or Momordica charantia L. is a vine plant. Bitter melon has been widely cultivated in tropical and subtropical countries such as India, Sri Lanka, Philippines, Japan, Australia, South America, Malaysia, China, Thailand, Vietnam, Laos, Myanmar, Cambodia, including Indonesia. ${ }^{2}$ Bitter melon is characterized by its bitter fruit taste, even so the Indonesian people have long used this plant as a daily food ingredient as well as alternative medicine because it has nutritious ingredients that are not found in other plants.

All parts of the plant, starting from the leaves, seeds, fruit, and roots of bitter melon have pharmacological effects that can cure various types of diseases. This can occur because bitter melon contains bioactive components that have hypoglycemic activity, immunomodulators, cancer chemoprevention, antiviral, antimicrobial, and inhibits oxidative stress and inflammation. The bioactive components contained in bitter melon include alkaloids, flavonoids, saponins, tannins, terpenoids, phenolics, and sterols. These components can have a good effect when given in appropriate doses, but can cause irritating toxic effects on the oral mucosa and digestive tract. Other compounds, namely $\alpha$-MMC and $\beta$-MMC, are also thought to cause abortion and inhibit embryo growth.

Another study conducted also proved that there was a toxic effect on the liver characterized by an increase in the levels of the SGOT and SGPT enzymes in the subchronic administration of bitter melon pulp ethanol extract to Wistar rats. This scientific evidence shows that the use of bitter melon in certain doses and for a long period of time has the risk of causing toxic effects on various organs of the body. One of the organs that is at risk of experiencing these toxic effects is the liver. ${ }^{5}$

Toxicity test is a test to detect the toxic effect of a substance and to obtain data on doses that can cause side effects. The subchronic toxicity test is performed to detect toxic responses that have not been detected in the acute toxicity test and to determine the toxic effects that can occur at longer exposure times. The principle of the subchronic oral toxicity test is

Cite this article: Ratwita W, Djamaludin M, Saadah H, Maharani S. Subchronic Toxicity of Ethanol Extract of Bitter Melon PULP (Momordica Charantia L.) on Liver Function and Histopathological Changes in Wistar Rats. Pharmacog J. 2021;13(4): 949-957. 
to detect the toxic effects that appear after repeated oral doses in test animals for a portion of the animal's lifespan, but not more than $10 \%$ of the entire age of the animal, i.e. for 28 or 90 days. This subchronic toxicity test can provide informative data regarding the long-term treatment of bitter melon. This toxicity test would be better if it could be continued to the chronic stage even in human clinical trials. ${ }^{6}$

One of the organs most susceptible to subchronic toxicity by bitter melon extract is the liver. The liver is the main target organ that has a function for metabolic processes and detoxification of foreign substances (xenobiotic) that enter the body, one of which is drugs. ${ }^{7-9}$ Most drugs that are administered orally are metabolized in the liver, which is the site of first-pass elimination or first-pass metabolism. ${ }^{8}$ Certain drugs given in high doses or over a long period of time can cause Drug Induced Liver Injury (DILI), thereby increasing the risk of liver dysfunction. DILI is characterized by elevated Aspartate Amino Transferase (AST) and Alanine Amino Transferase (ALT) and may present in different histopathological manifestations of hepatocellular disease with reversible and irreversible histopathological features.,10 The liver toxic response can also be observed by histopathological examination to assess liver damage.

\section{MATERIAL AND METHODS}

\section{Plant material}

Fresh Bitter melon or Momordica charantia L. was collected from Cipatat, West Java, Indonesia. It was harvested at 2 months old, and was identified and characterized in Sekolah Ilmu dan Teknologi Hayati, Institut Teknologi Bandung, Indonesia.

\section{Bitter melon extract preparation}

The pulp of the bitter melon washed and drained. The clean bitter melon pulp were sliced, then dehydrated in a dehydrator oven for $12 \mathrm{hrs}$ before milled by a machine to get the powder of bitter melon pulp. The powder of bitter melon pulp maserated with $96 \%$ ethanol until submerged. The vessel were tightly closed and protected from light for 1 day while repeatedly stirring. The maserate is placed in a porcelain dish, while additional ethanol were added to the remaining filtrat. Maceration is carried out 3 times. The filtrate being evaporated in a water bath until a thick extract is obtained.

\section{Experimental animal}

Normal both male and female Wistar rats were used for sub chronic toxicity study. The animals were 6-8 weeks old, weighting 150-200 g and were stabilized for seven days prior to the experiments. They were acclimatized at room temperature, with $12 \mathrm{~h}$ light and $12 \mathrm{~h}$ dark cycle, as well as free access to a standard pellet diet and water ad libitum. During acclimatization, the rats were randomized into experimental and control groups. All experimental procedures were in compliance with the Guide for the Care and Use of Laboratory Animals and approved by the local animal care committee, The Health Research Ethic Committee of Faculty of Medicine Universitas Padjajaran Bandung with ethical approval no 03/UN6.KEP/EC/2020.

\section{Sub chronic toxicity study}

Sub chronic toxicity study was performed according to the Organization of Economic Co-operation and Development (OECD) guideline. ${ }^{11}$ The animals were randomly divided as follows, Group 1 (control) and Group 2 treated with ethanol extract of bitter melon $(250 \mathrm{mg} / \mathrm{kgbw})$, Group 3 $(500 \mathrm{mg} / \mathrm{kgbw})$ and Group $4(1000 \mathrm{mg} / \mathrm{kgbw})$ respectively. Each group contained 5 animals/sex/group. The test preparation was given orally every day with a single dose. ${ }^{6}$ At the end of the 28 -day treatment period, all animal necropsied. All animals were fasted overnight prior to necropsy and euthanized by carbon dioxide inhalation. Relative organ weights, AST, ALT, histopathological changes were determined.

\section{Relative organ weight}

The liver were taken and weighed. The relative organ weight was calculated as follows:

Relative organ weight $=$ (organ weight $(\mathrm{g}) /$ body weight of the animal on sacrifice day (g)) x 100

\section{Biochemical analysis}

Blood samples were collected from a cardiac puncture in a nonheparinized tube, and then centrifuged at $10,000 \mathrm{rpm}$ for $5 \mathrm{~min}$. A serum was separated and analyzed for biochemical parameters on a Photometer 5010 V5+ based on an enzymatic colorimetric test, including aspartate aminotransferase (AST) and alanine aminotransferase (ALT), were determined by the kinetic method for the determination of AST and ALT activities according to the recommendation of the expert panel of the International Federation of Clinical Chemistry (IFCC). ${ }^{12,13}$

\section{Macroscopic study}

The liver were being observed to examined macroscopical changes before start the histopathological preparations. Macroscopic assessment of the liver was observed based on Robbins and Cotran's book pathologic basis of disease (Table 1).

\section{Histopathology study}

The first step of embedding (planting) is that the liver organ which has been immersed in formalin solution is removed and immersed in $70 \%$ ethanol for $24 \mathrm{~h}$, then transferred again and soaked in $80 \%$ ethanol for two hours; ethanol $90 \%$ for 20 minutes; $95 \%$ ethanol for 20 minutes, and then absolute ethanol for 20 minutes. Each step is repeated three times. The next treatment was immersion of the pancreas in a solution of xylol one and two for 20 minutes respectively and xylol three for 30 minutes at temperature $60-63^{\circ} \mathrm{C}$. Next, the liver is dipped in liquid paraffin and poured into a container. After a while the paraffin will harden and the pancreas is inserted into the paraffin block. Paraffin blocks are glued using a block holder and arranged parallel to the microtomic knife. The liver was cut to a thickness of $5 \mu \mathrm{m}$. The slices were cleaned with a brush and smeared with distilled water at room temperature, so that the tissue slices do not fold. The tissue slices are again brushed in warm distilled water at a temperature of $38-40^{\circ} \mathrm{C}$ to improve the folds that arise. Slices are stretched so that they are not folded back. The selected pieces are dried and placed on a plate at a temperature of $38-40^{\circ} \mathrm{C}$ for $24 \mathrm{~h}$.

The preparations were then colored with Hematoxylin-Eosin staining. Dehydration was done again using $70-96 \%$ alcohol. Cover the glass object using a glass deck using a balm (mounting). Tissue observation was then carried out microscopically from the preparations that had been made and the microscopic changes in the liver were recorded during the examination.

Microscopic examination of the liver was carried out by observing each preparation from the treatment and control groups under a light microscope. Histopathological examination was performed to determine the degree of liver fibrosis (staging) in chronic liver disease using the Metavir scoring system.

Table 1: Scores for the assessment of macroscopic morphology of the liver. ${ }^{14}$

\begin{tabular}{cc|}
\hline Area & Score \\
\hline Normal & 0 \\
Abnormal $<25 \%$ & 1 \\
Abnormal $26 \%-50 \%$ & 2 \\
Abnormal $51 \%-75 \%$ & 3 \\
Abnormal $76 \%-100 \%$ & 4 \\
\hline
\end{tabular}




\section{Statistical analysis}

Data were expressed as mean \pm standard deviation (SD) and analyzed statistically by Kruskal Wallis, continued with Mann Whitney test when data showed significant different $(\mathrm{p}<0.05)$ in Kruskal Wallis.

\section{RESULT}

\section{Biochemical analysis}

Based on Table 3, it can be seen that the levels of the AST and ALT enzymes in male rats at dose $250 \mathrm{mg} / \mathrm{kgbw}, 500 \mathrm{mg} / \mathrm{kgbw}$ and $1000 \mathrm{mg} /$ kgbw showed increased activity if compared to the control group, with the greatest increase in the group of male rats that treated with bitter melon extract $1000 \mathrm{mg} / \mathrm{kgbw}$.

AST and ALT level in group which treated with bitter melon extract 250 $\mathrm{mg} / \mathrm{kgbw}, 500 \mathrm{mg} / \mathrm{kgbw}$ and $1000 \mathrm{mg} / \mathrm{kgbw}$ showed significant increase compared to control group $(\mathrm{p}=0.000)$. The greatest increase in the average levels of AST and ALT level was greatest in the group treated with bitter melon extract $1000 \mathrm{mg} / \mathrm{kgbw}$. Each group showed different AST/ALT level, except between group 3 and 4.

The increase in AST and ALT in the treated rat suggests a toxic effect indicated by the increase in the results of hepatic enzyme tests that might caused by damage to the hepatic cells so that these enzymes will leave the cells and enter the blood circulation. This increase implies that the higher the dose given the higher the results of SGOT and SGPT examination which indicate toxic.

\section{Macroscopic examination}

Macroscopic examination in research is needed to determine abnormalities that can occur structurally. Macroscopic examination was observed by assessing the outer surface of the liver. The normal liver has a flat and smooth surface, while the abnormal liver has cysts, connective tissue, lumps, or abscesses.

Table. 6 showed the relative organ weights of the male and female rats after 28 days of administration of bitter melon extract. The relative organ weight of each organ evaluated and calculated at necropsy in the treatment groups did not showed a significant difference $(p>0.05)$ compared to the control.

The normality test using the Shapiro-Wilk Test showed an abnormal distribution $(\mathrm{p}<0.05)$. Therefore, statistical analysis was continued with the non-parametric Kruskal-Wallis test with significancy 0.207 ( $p>0.05$ ). Based on these results, the macroscopic examination of the ethanol extract of bitter melon pulp was not associated with liver toxicity in rats.

Cysts found in rats can be seen in Figure 1. Liver cysts in rats are often found in various experiments. The cause of cysts in rats was mostly due to tapeworm Cysts found in mice can be seen in Figure 1. Liver cysts in mice are often found in various experiments. The cause of cysts in rat was mostly due to tapeworm egg contamination in bedding powder. Based on another study that observed the incidence of cysticercosis, it was stated that 8 out of 24 rat infected with Cysticercus in the liver of the rat that looked healthy and did not develop pathological clinical symptoms so that the incidence of cysts found in this study might not related to bitter melon extract. ${ }^{16,17}$

The macroscopic structure that may arise in this study is the presence of liver organ scarring due to subchronic exposure, but on macroscopic observation, liver scar tissue was not found in both the control and treatment groups. Scar tissue can occur due to liver damage followed by a tissue repair process. Scar tissue is not visible if the fibrosis process in rats has not yet appeared massively on the entire liver surface. Another possibility that can occur is that the fibrosis that occurs is in the inner liver tissue so that the external examination cannot be found. The liver of rats with severe degree of fibrosis and diffuse may find nodules in cirrhosis of the liver. ${ }^{16,18}$

\section{Histopathological changes}

Figures 2 and 3 show the histopathology profile of male and female rats after 28 days of the administration of bitter melon extract. Light microscopic examination of the section of liver those treated with Bitter melon extract $250 \mathrm{mg} / \mathrm{kgbw}, 500 \mathrm{mg} / \mathrm{kgbw}$ and $1000 \mathrm{mg} / \mathrm{kgbw}$.

Histopathological examination of the liver was performed after macroscopic morphological examination of the liver. Hepatic preparations were made into histopathological preparations and examined microscopically. Microscopic examination is performed to determine the degree of liver damage by observing the degree of fibrosis in the liver chronically inflamed by bitter melon extract. The histopathological changes were scored based on Metavir fibrosis scoring by observing the presence of portal triad fibrosis at $100 \mathrm{x}$ and 400x magnifications.

The results of microscopic examination of $100 \mathrm{x}$ and $400 \mathrm{x}$ magnification in male and female control groups did not show fibrosis, while in the treatment group it was found that liver fibrosis was getting worse with increasing dose. The mean observations of the male group that treated with bitter melon extract $250 \mathrm{mg} / \mathrm{kgbw}$ showed fibrosis without septa around the portal triad and the female bitter melon extract $250 \mathrm{mg} /$ kgbw group showed fibrosis with a little septa around the portal triad.

Histopathologic changes in both male and female rats treated with bitter melon extract $500 \mathrm{mg} / \mathrm{kgbw}$ showed fibrosis with a little septa around the portal triad. The histopathological changes in the male rats treated with bitter melon extract $1000 \mathrm{mg} / \mathrm{kgbw}$ showed fibrosis with many septa around the portal triad and the female rats treated with bitter melon extract $1000 \mathrm{mg} / \mathrm{kgbw}$ showed fibrosis with a few septa around the portal triad.

Due to the data distribution was not normal, so the statistical analysis was continued with the non-parametric Kruskal-Wallis test with significancy 0.001 in male rats $(p>0.05)$, and $0.002(p>0.005)$ in female

Table 2: Metavir Scoring System. ${ }^{15}$

\begin{tabular}{cc}
\hline Score & Criteria \\
\hline F0 & Portal inflammation \\
F1 & Portal fibrosis without septa \\
F2 & Portal fibrosis and few septa \\
F3 & Numerous septa without cirrhosis \\
F4 & Cirrhosis \\
\hline
\end{tabular}


Table 3: AST and ALT level in male rat group.

\begin{tabular}{ccc}
\hline Group & AST & ALT \\
\cline { 2 - 3 } & Mean \pm SD & Mean \pm SD \\
\hline Control & $21.20 \pm 5.03$ & $57.24 \pm 13.88$ \\
Bitter melon extract $250 \mathrm{mg} / \mathrm{kgbw}$ & $48.47 \pm 35.99$ & $201.65 \pm 123.07$ \\
Bitter melon extract $500 \mathrm{mg} / \mathrm{kgbw}$ & $108.34 \pm 65.87$ & $287.93 \pm 63.60$ \\
Bitter melon extract $1000 \mathrm{mg} / \mathrm{kgbw}$ & $246.46 \pm 322.51$ & $364.48 \pm 279.79$
\end{tabular}

Table 4: AST and ALT level.

\begin{tabular}{ccc}
\hline Group & AST & ALT \\
\cline { 2 - 3 } Control & Mean \pm SD & Mean \pm SD \\
\hline Bitter melon extract $250 \mathrm{mg} / \mathrm{kgbw}$ & $24.01 \pm 6.04$ & $1.60 \pm 0.77$ \\
Bitter melon extract $500 \mathrm{mg} / \mathrm{kgbw}$ & $46.03 \pm 34.30$ & $155.08 \pm 63.23$ \\
Bitter melon extract $1000 \mathrm{mg} / \mathrm{kgbw}$ & $56.25 \pm 17.52$ & $245.54 \pm 150.32$ \\
\end{tabular}

Table 5: AST and ALT in Mann Whitney test.

\begin{tabular}{cccccc}
\hline \multirow{2}{*}{ Group } & & \multicolumn{3}{c}{$\mathrm{p}$} \\
\cline { 3 - 6 } & & 1 & 2 & 3 & 4 \\
AST & 1 & & $0.011^{*}$ & $0.000^{*}$ & $0.000^{*}$ \\
& 2 & $0.011^{*}$ & & $0.043^{*}$ & $0.009^{*}$ \\
& 3 & $0.000^{*}$ & $0.043^{*}$ & & 0.315 \\
& 4 & $0.000^{*}$ & $0.009^{*}$ & $0.315^{*}$ & \\
ALT & 1 & & $0.000^{*}$ & $0.000^{*}$ & $0.000^{*}$ \\
& 2 & $0.000^{*}$ & & $0.029^{*}$ & $0.028^{*}$ \\
& 3 & $0.000^{*}$ & $0.029^{*}$ & & 0.315 \\
& 4 & $0.000^{*}$ & $0.028^{*}$ & 0.315 & \\
\hline
\end{tabular}

Values are expressed as the mean $\pm \mathrm{SD} ;{ }^{*}$ significantly different from the control group $(\mathrm{p}<0.05)$ with Mann Whitney test

Table 6: Relative organ weight (ROW).

\begin{tabular}{cccc} 
Group & Sex & ROW $(\mathrm{g})$ & P \\
\cline { 3 - 3 } Control & Male & $2.57 \pm 0.55$ & \\
& Female & $3.18 \pm 0.37$ & \\
Bitter melon extract $250 \mathrm{mg} / \mathrm{kgbw}$ & Male & $3.32 \pm 0.80$ & 0.177 \\
& Female & $3.72 \pm 0.64$ & $3.08 \pm 0.82$ \\
Bitter melon extract $500 \mathrm{mg} / \mathrm{kgbw}$ & Male & $2.89 \pm 0.56$ & $3.07 \pm 0.34$ \\
Bitter melon extract $1000 \mathrm{mg} / \mathrm{kgbw}$ & Female & $3.57 \pm 1.44$
\end{tabular}

Values are expressed as the mean $\pm S D$, analized with Kruskal Wallis test

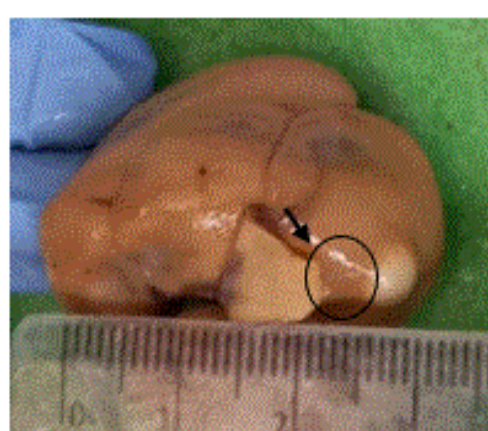

(a)

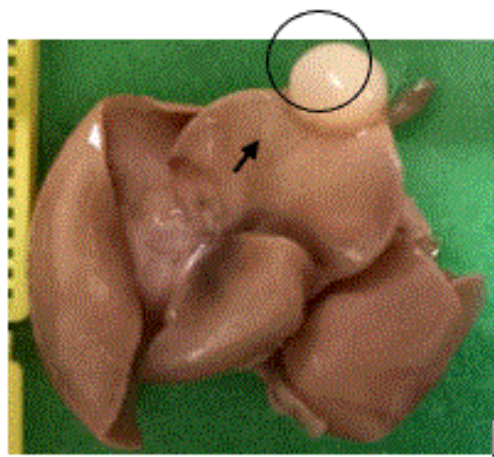

(b)

Figure 1: Macroscopic description of rat liver morphology. Notes: (a) Cyst in male control group; (b) Cysts in female rat group 1. 
Table 7: Observations of the macroscopic morphological description of the liver.

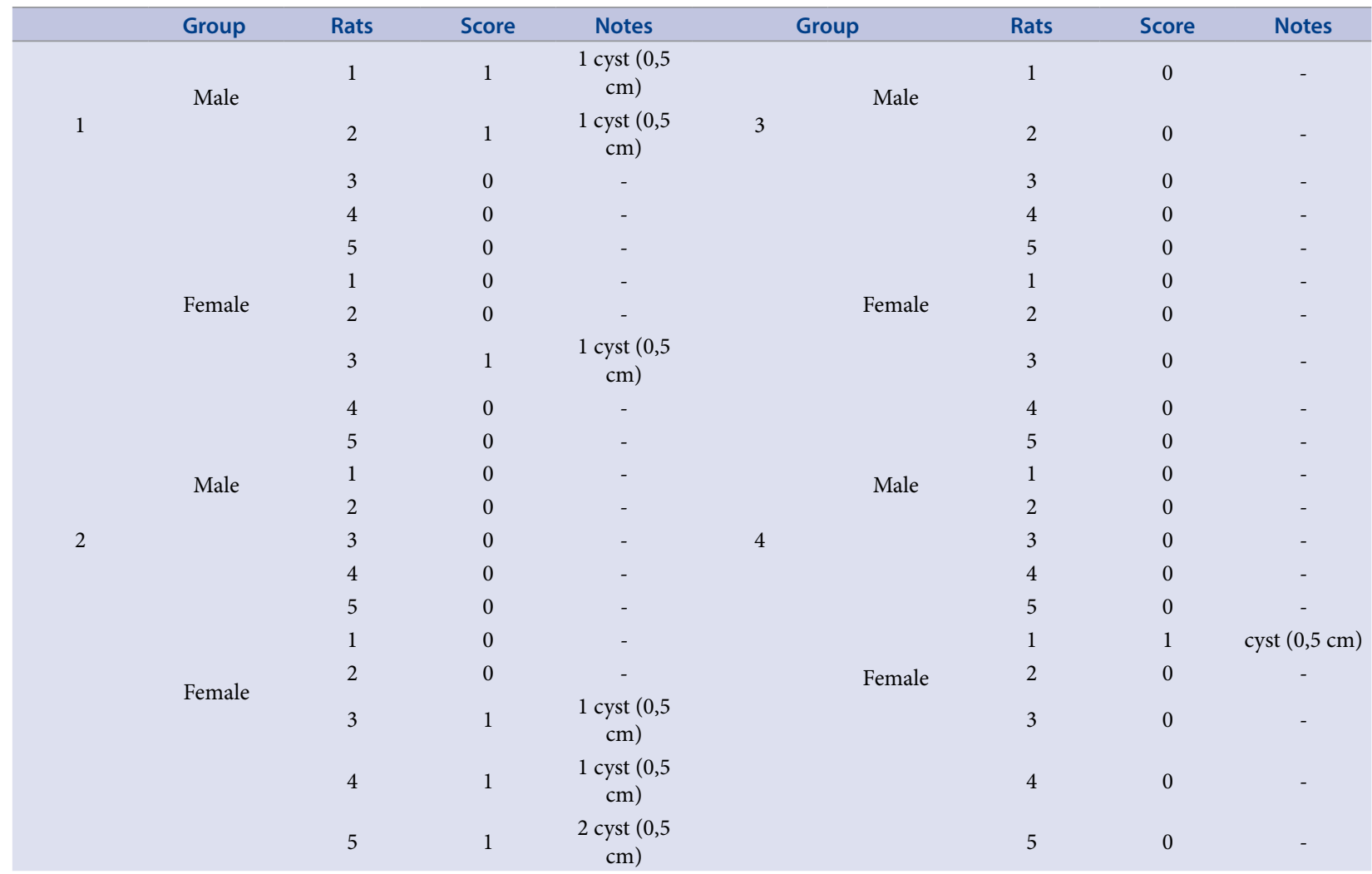

Notes:

Normal: 0; Abnormal <25\%: 1; Abnormal 26\%-50\%: 2; Abnormal 51\%-75\%: 3; Abnormal 76\%-100\%: 4; Group 1: Control, not given any treatment except water and pellets; Group 2: bittermelon extract 250 mg/kgbw; Group 3: 500 mg/kgbw; Group 41000 mg/kgbw, respectively.

Table 8: Histopathologic results with Metavir fibrosis score.

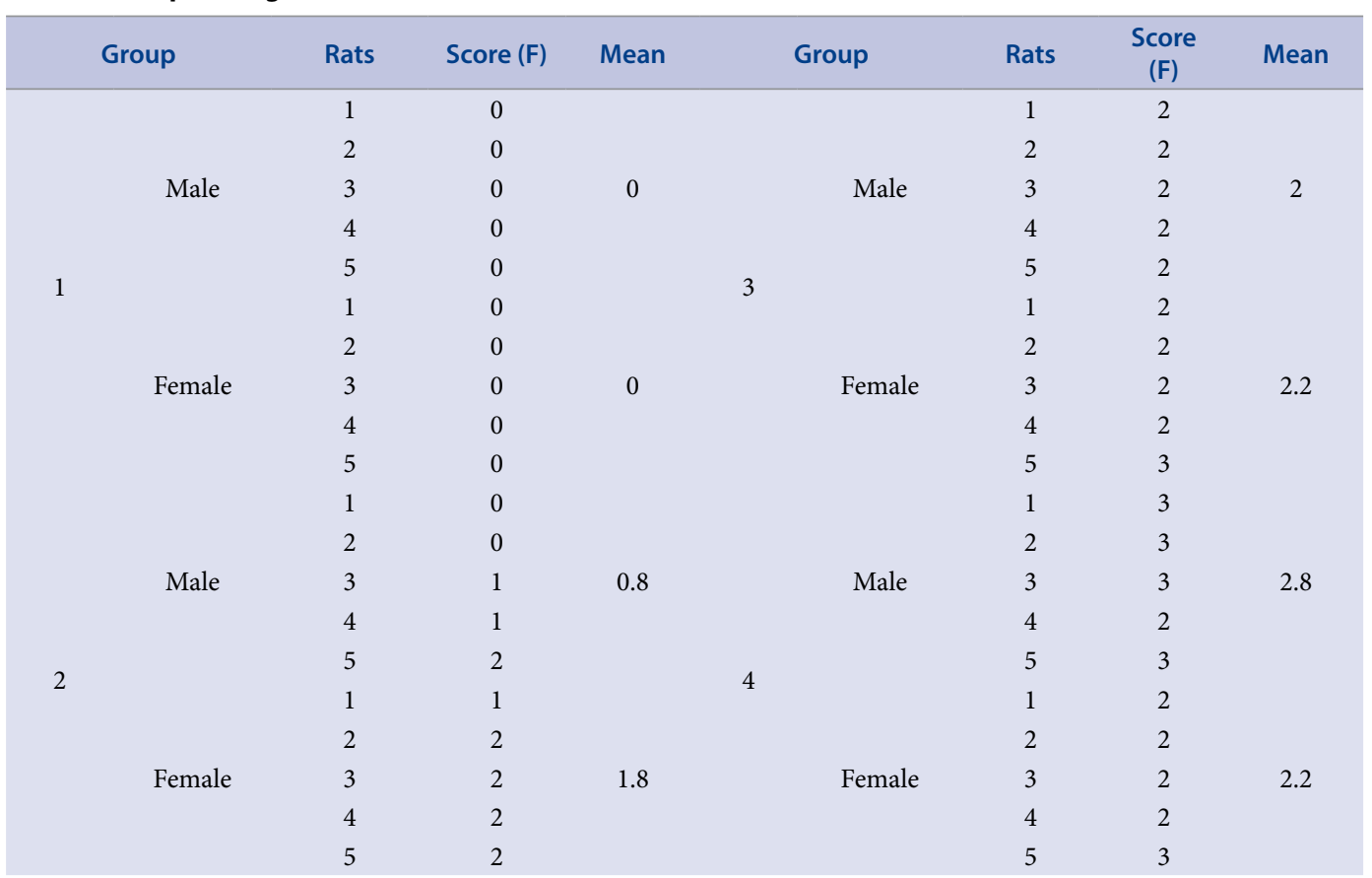

Notes:

*: Score (F) 0: Portal inflammation; 1: Portal fibrosis without septa; 2: Portal fibrosis with slight septa; 3: There are many septa without cirrhosis; 4: Cirrhosis. Group 1: Control, not given any treatment except water and pellets; Group 2: bitter melon extract 250 mg/kgbw, Group 3: 500 mg/kgbw, Group 4: 1000 mg/kgbw. 
Table 9: Post Hoc Mann-Whitney results for Metavir fibrosis score.

\begin{tabular}{|c|c|c|c|c|c|c|}
\hline \multirow{2}{*}{\multicolumn{2}{|c|}{ Group }} & \multirow{2}{*}{ Mean } & \multicolumn{4}{|c|}{$p$} \\
\hline & & & Group 1 & Group 2 & Group 3 & Group 4 \\
\hline \multirow{4}{*}{ Male } & 1 & 0.0 & & 0.053 & $0.003^{*}$ & $0.004^{*}$ \\
\hline & 2 & 0.8 & 0.053 & & $0.018^{*}$ & $0.009^{*}$ \\
\hline & 3 & 2.0 & $0.003^{*}$ & $0.018^{\star}$ & & $0.014^{*}$ \\
\hline & 4 & 2.8 & $0.004^{*}$ & $0.009^{*}$ & $0.014^{*}$ & \\
\hline \multirow{4}{*}{ Female } & 1 & 0.0 & & $0.004^{*}$ & $0.004^{*}$ & $0.004^{*}$ \\
\hline & 2 & 1.8 & $0.004^{*}$ & & 0.180 & 0.180 \\
\hline & 3 & 2.2 & $0.004^{*}$ & 0.180 & & 1.000 \\
\hline & 4 & 2.2 & $0.004^{*}$ & 0.180 & 1.000 & \\
\hline
\end{tabular}

Notes:

${ }^{*}: \mathrm{p} \leq 0.05$ (there is a significant difference)

Group 1: Control, not given any treatment except water and pellets; Group 2: bitter melon extract $250 \mathrm{mg} / \mathrm{kgbw}$, Group 3: $500 \mathrm{mg} / \mathrm{kgbw}$, Group 4: $1000 \mathrm{mg} / \mathrm{kgbw}$, respectively

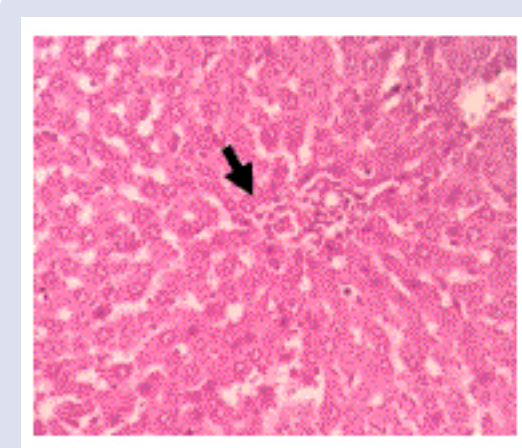

(a)

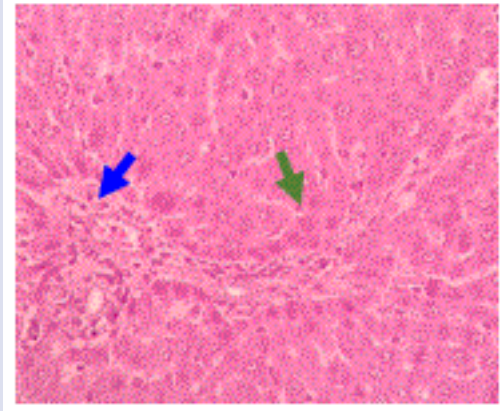

(c)

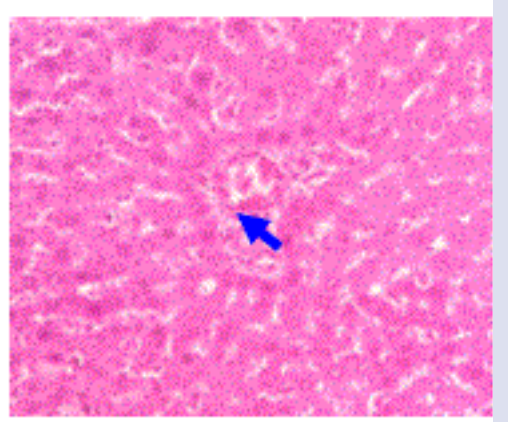

(b)

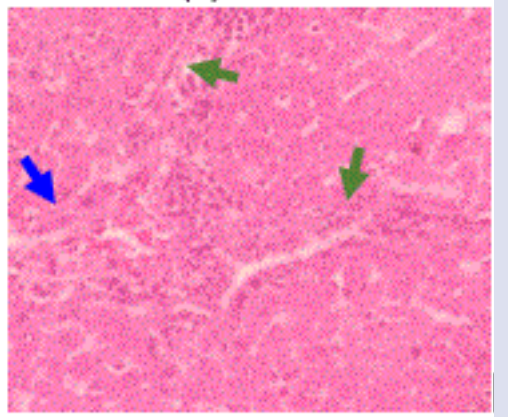

(d)

Figure 2: Histopathological examination ( $\mathrm{HE}, 400 \mathrm{x})$ of liver's male rats in a subchronic oral toxicity study. Black arrow: normal portal triad, blue arrow: portal triad fibrosis, green arrow: septa fibrosis. (a) Control group; (b) bitter melon extract $250 \mathrm{mg} / \mathrm{kgbw}$, (c) $500 \mathrm{mg} /$ $\mathrm{kgbw}$; (d) $1000 \mathrm{mg} / \mathrm{kgbw}$, respectively.

rats. Then data analysis was continued with the Post Hoc MannWhitney test to determine the significant difference in each group.

Based on the results of the analysis, it can be concluded that there is a significant difference between the control group and the treatment group, both male and female rats. This is due to the consumption of bitter melon extract $250 \mathrm{mg} / \mathrm{kgbw}, 500 \mathrm{mg} / \mathrm{kgbw}$, and $1000 \mathrm{mg} / \mathrm{kgbw}$ treated for 28 days.

\section{DISCUSSION}

Liver was an organ that have an important role in the metabolism process of the ethanol extract of bitter melon, so the extract given will enter the enterohepatic cycle and the detoxification process in the liver. This process was related to an enzyme in the liver, namely cytochrome P450. This enzyme could metabolize foreign substances in the body so the toxicity of these substances will decrease. This metabolism process also made it easier to dissolve in water and easy to remove from the body.
Research that conducted the subchronic toxicity test by Desmukh (2016) showed normal liver morphology in the treatment group. Another study that provided a therapeutic dose of concentrated bitter melon infusion by Arif (2016) also did not find macroscopic abnormalities of the liver. ${ }^{16,17}$ There is no evidence that bitter melon can cause toxicity in macroscopic liver morphology, but hepatotoxins in bitter melon might cause damage at the cellular level. ${ }^{3,17}$

Previous research conducted by Saeed (2016) showed different results. Research conducted by Saeed (2016) did not show any significant differences between the control and treatment groups given a single dose of bitter melon ethanol extract at a dose of $100 \mathrm{mg} / \mathrm{kgbw}, 500$ mg/kgbw, $1000 \mathrm{mg} / \mathrm{kgbw}, 2000 \mathrm{mg} / \mathrm{kgbw}, 4000 \mathrm{mg} / \mathrm{kgbw}$, and $500 \mathrm{mg} /$ kgbw/day for 7 days on histopathological examination and hepatic enzymes. This is related to the administration of low doses and a short time so that it has not caused a toxic effect on the microscopic image of the liver. ${ }^{19,20}$ 
Giving certain doses of bitter melon can have a good effect on the liver. Bitter melon contains polysaccharides that can inhibit oxidative stress so that low doses can be hepatoprotective. ${ }^{4,21-23}$ Another study conducted by Abdillah (2020) showed that giving the ethanol extract of bitter melon fruit for 28 days at a dose of $40 \mathrm{mg} / \mathrm{kgbw}, 80 \mathrm{mg} / \mathrm{kgbw}$, and $320 \mathrm{mg} / \mathrm{kgbw}$ did not show a significant increase in liver enzymes and changes in the histological structure of the liver, but there has been an inflammatory process characterized by infiltration of inflammatory cells accompanied by sinusoid dilatation. ${ }^{24}$

Liver damage only occurs in high doses and over a long period of time, beginning with an acute inflammatory response that progresses to chronic inflammation. The toxicity test conducted by Taek (2020) by administering bitter melon infusoria at a dose of $1250 \mathrm{mg} / \mathrm{kgbw}$ and $2500 \mathrm{mg} / \mathrm{kgbw}$ for 48 days showed inflammatory cell infiltration and hepatocyte damage in the acute phase in the form of hydropic degeneration, fatty degeneration, and necrosis. ${ }^{25-26}$ The different types of drug preparations can be one of the causes of the different degrees of damage that occurs. The condition of the research tools and materials as well as the observer's ability to assess histopathological preparations were also factors that influenced the results of the study. ${ }^{24}$

Bitter melon extract that is consumed will enter the digestive tract and be absorbed by the small intestine to be carried to the liver through the portal vein of the hepatica. ${ }^{27}$

Bitter melon extract enters the liver as xenobiotics and is metabolized through phase I and phase II reactions. The phase I reaction (nonsynthetic reaction) consists of oxidation, reduction, and hydrolysis, which will be followed by a phase II reaction (synthetic reaction) which involves conjugation with endogenous substances so that the metabolites that have gone through phase II produce a more polar form and are easily excreted in form of urine and bile. The enzyme that plays an important role in phase I is cytochrome P450. Medicines can inhibit the action of the cytochrome $\mathrm{P} 450$ enzyme. The oxidation process that is not optimal in stage I will cause an imbalance of metabolism in phase II, resulting in the accumulation of drug metabolites which can cause liver tissue damage..$^{28,29}$

Damage in the early stages will cause acute phase inflammation, but if the acute phase inflammatory process fails to eliminate drugs such as Bitter melon extract by subchronic administration, the inflammatory process will continue. The injured cells will secrete ROS, TNF, IL1 , and lymphotoxin which will activate stellate cells to produce myofibroblasts. Activation of these stellate cells will secrete cytokines which will stimulate the activation of other stelate cells, resulting in liver fibrosis. ${ }^{30,31}$

Fibrosis that occurs is influenced by the dose of Bitter melon extract given to rats. The higher the dose given, the more severe and progressive the liver fibrosis will occur. The fibrosis process that occurs progressively as in the treatment group 3 males and females can lead to the formation of bridging fibrosis, namely the formation of fibrosis across the portal triad or between the portal triad and the central vein, but the hepatic architecture still tends to be intact and reversible. Bridging fibrosis that has formed completely around the hepatocytes will form nodules (cirrhosis) which are irreversible and damage the hepatic architecture. Cirrhosis of the liver is a risk of developing liver cancer. ${ }^{18,30-31}$

\section{CONCLUSIONS}

Based on the results of research that has been carried out, the ethanol extract of bitter melon pulp at a dose of $250 \mathrm{mg} / \mathrm{kgbw}, 500 \mathrm{mg} / \mathrm{kgbw}$, and $1000 \mathrm{mg} / \mathrm{kgbw}$ affect liver function significantly. But it does not have a subchronic toxicity effect on relative organ weight and macroscopic changes in liver morphology. Otherwise, there was subchronic toxicity effect on changes in the microscopic structure of the liver characterized by the formation of fibrosis in the liver portal triad of experimental animals.

Further research needs to be carried out histopathological examination for histopathological observation by assessing the degree of hepatocyte cell damage and continuing the advanced toxicity test, namely the chronic toxicity test.

\section{ACKNOWLEDGEMENT}

This work was supported by Jenderal Achmad Yani University and School of Pharmacy, Bandung Institute of Technology, Indonesia.

\section{REFERENCES}

1. Ministry of Trade of the Republic of Indonesia. Traditional Herbal Medicine. Obat Herbal Tradisional. 2014;(September):1-20.

2. Bangun A. Ensiklopedia Tanaman Obat Indonesia. Bandung: Bandung Indonesia Publishing House; 2012.

3. National Center for Chronic Disease Prevention and Health Promotion (NCCDPHP). About Chronic Diseases [Internet]. CDC. 2019. Available from: https://www.cdc.gov/chronicdisease/about/index.htm

4. Bharathi LK, Joseph John K. Momordica Genus in Asia : An Overview. In India: Springer; 2013. p. 1-3.

5. Jia S, Shen M, Zhang F, Xie J. Recent advances in momordica charantia: Functional components and biological activities. Int $\mathrm{J}$ Mol Sci. 2017;18(12).

6. Rozario R, Ramakrishna B. Histopathological study of chronic hepatitis B and C: A comparison of two scoring systems. J Hepatol. 2003;38(2):223-9.

7. Badan Pengawas Obat dan Makanan. Pedoman Uji Toksisitas Nonklinik Secara In Vivo. 2014;2014(June):1-2.

8. Hall, John. Guyton Text book of medical physiology, $13^{\text {th }}$ ed. Singapura: Elsevier; 2015. p. 806-9

9. Djamaluddin M. Introduction of Pharmacology, 1st ed. Jakarta: PT RajaGrafindo Persada; 2017. p. 43-73.

10. Deshmukh NS. Safety assessment of McB-E60 (extract of a Momordica sp.): Subchronic toxicity study in rats. Toxicol Reports [Internet]. 2016;3:481-9. Available from: http://dx.doi.org/10.1016/j. toxrep.2016. 05.006

11. Bashir A, Sarwal P, Mehta D. Liver Toxicity. NCBI [Internet]. 2020 Available from: https://www.ncbi.nlm.nih.gov/books/NBK526106/

12. OECD Guidelines for The Testing of Chemicals: Acute Oral ToxicityFixed Dose Procedure, OECD/OCDE 420. Adopted: 17th December 2001

13. Tietz, N.W.; Rinker, A.D.; Shaw, L.M. IFCC Methods for the measurement of catalytic concentration of enzymes, IFCC Method for Alkaline Phosphatase. J. Clin. Chem. Clin. Biochem. 1983, 21 , 731-748.

14. Bergmeyer, H.U.; Horder, M.; Rey, J. Approved recommendation on IFCC methods for the measurement of catalytic concentration of enzymes, IFCC method for Alanine Aminotransferase. J. Clin. Chem. Clin. Biochem. 2006, 24, 481-495.

15. Kumar V, Abbas AK, Aster JC. Robbins Basic Pathology: 9'th ed. Nasar IM, Cornain S, editors. Singapore: Elsevier; 2015.

16. Supriono S, Pratomo B, Praja DI. Pengaruh Kurkumin Terhadap Kadar NF-kB dan Derajat Fibrosis Hati pada Tikus Fibrosis Hati. J Penyakit Dalam Indones. 2019;5(4):174-83

17. Berata IK, Agung A, Arjana G, Sudira IW, Merdana IM, Budiasa IK et al. Studi Patologi Kejadian Cysticercosis pada Tikus Putih. J Vet. 2010;11(4):232-7.

18. Sharma R, Tiwari K, Birmingham K, Armstrong E, Montanez A, Guy $R$, et al. Cysticercus fasciolaris in Brown Rats (Rattus norvegicus) in Grenada, West Indies. J Parasitol Res. 2017;2017. 
19. Axley P, Mudumbi S, Sarker S, Kuo YF, Singal AK. Patients with stage 3 compared to stage 4 liver fibrosis have lower frequency of and longer time to liver disease complications. PLoS One. 2018;13(8):111.

20. Mardani S, Khodadadi S, Ahmadi A, Kazemi E, Rafieian-Kopaei M The effects of Momordica charantia on liver function and histological structure Annals of Research in Antioxidants. Ann Res Antioxidants. 2016;1(1):12.

21. Kietzmann T, Dimova EY, Flügel D, Scharf JG. Oxygen: Modulator of physiological and pathophysiological processes in the liver. Z Gastroenterol. 2006;44(1):67-76.

22. Sagor AT, Chowdhury MRH, Tabassum N, Hossain H, Rahman MM, Alam MA. Supplementation of fresh ucche (Momordica charantia L. var. muricata Willd) prevented oxidative stress, fibrosis and hepatic damage in $\mathrm{CCl} 4$ treated rats. BMC Complement Altern Med. 2015;15(1):1-9.

23. Abdollahi M, Zuki ABZ, Goh YM, Rezaeizadeh A, Noordin MM. The effects of Momordica charantia on the liver in streptozotocin-induced diabetes in neonatal rats. African J Biotechnol. 2010;9(31):5004-12.

24. Deng $Y$, Tang $Q$, Zhang $Y$, Zhang $R$, Wei Z, Tang $X$, et al. Protective effect of Momordica charantia water extract against liver injury in restraint-stressed mice and the underlying mechanism. Food Nutr Res [Internet]. 2017:61(00). Available from: https://doi. org/10.1080/16546628. 2017.1348864
25. Abdillah S, Inayah B, Febrianti AB, Nafisa S. Acute and Subchronic Toxicity of Momordica Charantia L Fruits Ethanolic Extract in Liver and Kidney. Syst Rev Pharm. 2020;11(12):2249-55.

26. Taek AY, Ndaong NA, Gaina CA, Cendana UN. Gambaran histopatolog hepar tikus putih (Rattus norvegicus) jantan pasca pemberian ekstrak infusa buah pare (Momordica charantia L. ) lokal. J Vet Nusant. 2020;3(2).

27. Abdelhalim MAK, Jarrar BM. Gold nanoparticles induced cloudy swelling to hydropic degeneration, cytoplasmic hyaline vacuolation, polymorphism, binucleation, karyopyknosis, karyolysis, karyorrhexis and necrosis in the liver. Lipids Health Dis [Internet]. 2011;10(1):166. Available from: http://www.lipidworld.com/content/10/1/166

28. Gartner LP, Hiatt JL. Sistem Pencernaan: Kelenjar. In: Suryono IAS Damayanti L, Wonodirekso S, editors. Buku Ajar Berwarna Histologi. 3rd ed. Singapura: Elsevier Saunders; 2014. p. 399-420.

29. McDonnell AM, Dang CH. Basic Review of the Cytochrome P450 System. JADPRO. 2013;

30. Teschke R, Schwarzenboeck A, Hennermann KH. Causality assessment in hepatotoxicity by drugs and dietary supplements. $\mathrm{Br} \mathrm{J}$ Clin Pharmacol. 2008;66(6):758-66.

31. Ismail M, Pinzani M. Reversal of liver fibrosis. Saudi J Gastroenterol. 2009;15(1):72-9.

32. Böttcher K, Pinzani M. Pathophysiology of liver fibrosis and the methodological barriers to the development of anti-fibrogenic agents. Adv Drug Deliv Rev. 2017;121:3-8. 


\section{ABOUT AUTHORS}

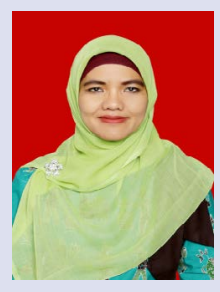

Welly Ratwita, Pharmacology lecturer at the Medical Faculty, Jenderal Achmad Yani University. Completed medical school and master degree at the Medical Faculty of Padjadjaran University and Doctoral degree at Institut Teknologi Bandung, Indonesia.

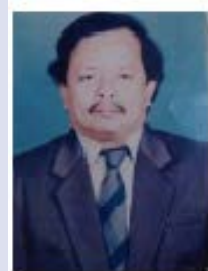

A GP for more than 30 years and a lecturer for more than 40 years, specializing in Pharmacology, Forensic Toxicology, and Islamic Perspective on Medical Technology.

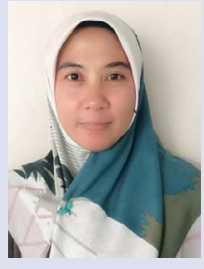

Hindun Saadah, anatomy lecturer at the Medical Faculty, Jenderal Achmad Yani. Born in Bandung, December 24, 1977. Completed medical school at the Medical Faculty of Jenderal Achmad Yani and a Masters at the University of Indonesia

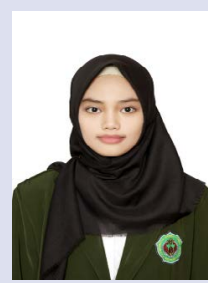

Salsalbilla Maharani Achda is currently a clinical student in Faculty of Medicine in Jenderal Achmad Yani University, Cimahi, Indonesia.

Cite this article: Ratwita W, Djamaludin M, Saadah H, Maharani S. Subchronic Toxicity of Ethanol Extract of Bitter Melon PULP (Momordica Charantia L.) on Liver Function and Histopathological Changes in Wistar Rats. Pharmacog J. 2021;13(4): 949-957. 